\title{
Partnerships with the Private Sector: Success Factors and Levels of Engagement in Development Cooperation
}

\author{
Jorge A. Pérez-Pineda and Dorothea Wehrmann
}

\subsection{INTRODUCTION}

Practitioners and researchers alike increasingly regard the private sector ${ }^{1}$ as a crucial partner for development cooperation (e.g. Nelson and Prescott 2008; Pingeot 2014). Also, international agreements such as the Monterrey Consensus (2002), the Busan Declaration (2011), the Rio+20 outcome document (2012), and the Addis Ababa Action Agenda (2015) all encouraged the formation of public-private partnerships (PPPs) (Pérez-Pineda 2017). With the 2030 Agenda for Sustainable Development, the private sector is considered to be more important than ever. It is a widespread narrative that states need to cooperate with the private sector in order to access knowledge (such as technical expertise) (The North-South Institute 2013) and to fill financial gaps of up to \$2.5 trillion annually to implement the Sustainable Development Goals (SDGs) (United Nations Conference on Trade and Development [UNCTAD] 2015, p. 7; United Nations Development Programme 2017). Particularly international organisations such as the Organisation for Economic Co-operation and Development (OECD), the World Bank, and numerous agencies and programmes affiliated with the United Nations (UN) have focussed on the means to incentivise and better include the private sector in

\section{J. A. Pérez-Pineda $(\otimes)$}

Universidad Anáhuac México, Huixquilucan, Estado de México, México

D. Wehrmann

German Development Institute / Deutsches Institut für Entwicklungspolitik (DIE), Bonn, Germany

e-mail: Dorothea.wehrmann@die-gdi.de

(C) The Author(s) 2021 
the development agenda-however, the success so far has been limited (United Nations 2009; Organisation for Economic Co-operation and Development [OECD] 2011; International Labour Organization 2017).

The overall forms of engagement and the contributions of private-sector actors are often not clear. Moreover, researchers have reviewed arrangements with "the business and/or philanthropic sector" often negatively, for example, as providing "limited means to secure the mandated responsibilities of the UN, and [as being] far from transformative in terms of long-term development" (Adams and Martens 2015, p. 113). Instead, actors from the private sector are often considered to be trying to polish their reputations via their engagements in development cooperation (Beisheim and Liese 2014; Said et al. 1995). Particularly partnerships with more powerful multi-national companies are seen to be potentially reproducing patterns of domination, exclusion, and geographical asymmetry (Pattberg and Widerberg 2014). Without regulatory oversight, "progressive, just development outcomes" thus seem uncertain (Mawdsley 2015, 2018).

Others hope that the inclusion of private-sector actors in policy dialogues may influence the negotiation of priorities-ideally, such dialogues may also inspire changing behaviours as a result of "mutual appreciation and learning" (Altenburg 2005, p. 4). Similarly, the more private-sector actors that become involved, discourses and peer-pressure are also seen as means to further "stimulate business solutions that contribute to development" (Davis 2011, p. 17; see also Kindornay and Reilly-King 2013, p. vii, and Tienhaara et al. 2012, p. 47).

Specifically in development cooperation at the country level, however, in many cases private-sector engagement had not proven to be effective (Beisheim and Liese 2014; Romero 2015), as companies focussed on their profits, while some used the SDGs primarily to sell new products and access new markets (Abshagen et al. 2018, p. 7). Still, national development agencies often pursue the strategy of multi-stakeholder approaches that include actors from the private sector in order to reach development goals (Altenburg 2005). This has also been a common practice in the context of South-South cooperation, which has been ascribed a salient role for achieving the 2030 Agenda (United Nations General Assembly 2018), but the quality of these partnerships are being discussed more often in recent years. ${ }^{2}$ At the Development Cooperation Forum Argentina High-Level Symposium, for example, the participants agreed on five areas for further work in the preparations for BAPA+40 (the 40th Anniversary of the Buenos Aires Plan of Action on the promotion and implementation of technical cooperation among developing countries). They stated, among other things: "South-South and triangular cooperation must take inclusiveness to a new level. They can help shift the focus beyond expanding partnerships, to fostering quality multi-stakeholder engagement that can improve the livelihoods and wellbeing of people" (Development Cooperation Forum 2017, p. 6, emphasis added). 
While arguing in favour of multi-stakeholder partnerships, at the same time they demanded more quality to meet the shared objective of BAPA +40 and the 2030 Agenda: to transform the world for the better. In this regard, previous research has shown that strategies to incentivise and enhance partnerships with the private sector need to be context- and actor-specific to be successful. Country-specific regulations, the capacities and internal structures of private-sector actors (e.g. between state- and shareholder-owned businesses), as well as the political intentions linked to their engagement in development cooperation differ (Byiers et al. 2015; Chan 2014; Wehrmann 2018). Multi-stakeholder approaches that consider such individual factors may foster their quality (understood here as success in terms of envisioned outcomes) by enhancing the identification and agreement on shared objectives, responsibilities, and monitoring mechanisms, while limiting the possibilities to dominate cooperation in multi-stakeholder partnerships for the sake of individual benefits. But how can this be done in practice?

Concepts of indirect governance, such as the approach of orchestration, guide different actors that share a similar goal and thus support the consideration of individual factors (Abbott et al. 2016; Chan and Pauw 2014). Orchestrators (e.g. multi-stakeholder platforms) provide ideational and material support to like-minded intermediaries (e.g. multi-actor partnerships or partnering countries), who then address individual targets or target groups (e.g. private-sector actors). In this chapter, we apply this concept by considering different levels of engagement for private-sector actors under the current development agenda: We show that it matters whether it is envisioned to incentivise and regulate private-sector engagement at the global level (e.g. in multi-stakeholder platforms) or at the country level (e.g. with development agencies). Under consideration of these different levels, this chapter examines the question of how partnerships with private-sector actors can become more successful to achieve the 2030 Agenda.

Specifically, this chapter cites two cases of multi-stakeholder partnerships that aim at advancing the implementation of the SDGs at the global level or at the country level by enhancing the engagement of actors from the private sector. This is done in order to show how partnerships apply different strategies to use opportunities and meet challenges that result from their scope. First, we shed light on the case of the Global Partnership for Effective Development Co-operation (GPEDC), a multi-stakeholder platform and multi-actor partnership that intends to be inclusive and global in scope. Different from the majority of multi-actor partnerships, which mainly focus on the means to co-finance sustainable development initiatives when engaging with the private sector, the GPEDC is one of the very few partnerships intending to enhance public-private dialogue and knowledge-sharing (Global Partnership for Effective Development Co-operation [GPEDC] 2018). Due to its global approach, however, it faces the challenge of remaining either rather general or too specific to apply to every SDG partnership (Wehrmann 2018). In this regard, the cases considered at the national level, on the other hand, 
provide a better understanding of context-specific particularities. The Alliance for Sustainability (AS) serves as one such example: It was one of the first formal initiatives of the Mexican Agency for International Development Cooperation (Agencia Mexicana de Cooperación Internacional para el Desarrollo, AMEXCID) that incorporates the private sector in its strategy to implement the 2030 Agenda. A central challenge that the AS has been facing is to advance institutional capacities to implement projects of the AS and to support its sustainability (Agencia Mexicana de Cooperación Internacional para el Desarrollo [AMEXCID] 2018; Pérez-Pineda 2017). Considering the cases of the GPEDC and of the AS allows us to identify the different challenges and related potentials of private-sector engagement when contributing to development initiatives as knowledge or resource providers at the national and global levels.

This work builds on a desk-based analysis of policy papers, reports, and secondary literature. It also considers information gained from interviews with researchers who focus on multi-stakeholder networks and from political practitioners engaged in the GPEDC and in South-South cooperation. First, this chapter introduces the more general debate on private-sector engagement in development cooperation and discusses the different types of-and relevance ascribed to-multi-actor partnerships. Second, we differentiate between internal and contextual challenges, and we introduce the means to support the success of private-sector engagement in development cooperation in this regard. Third, by investigating specific cases (the GPEDC and the AS), this chapter cites the diversity of private-sector actors and their potentials for engaging at different levels in development cooperation. Based on these cases, this chapter further investigates how the concept of orchestration may enhance the impact of private-sector engagement to achieve the 2030 Agenda. It is important to say that since the current analysis is based on a qualitative approach, there is not a ranking for which the achievements or accomplishments within the framework can be graded. Instead, the cases are helpful for illustrating how internal and contextual challenges in partnerships are adapted and overcome. The last and concluding section summarises the central results for paving the way towards more successful private-sector engagement in development cooperation.

\subsection{Classification ANd Relevance of Partnerships with Actors from the Private Sector in the Context of the SDGs}

In the context of the SDGs, the inclusion of the private sector in development cooperation is still contested: Although some hope that companies will address social and environmental challenges and still make a profit (OECD 2018b), others fear that private-sector actors may hijack the 2030 Agenda to access new markets (GPEDC 2019). This fear is also spurred by the multiplicity and diversity of partnerships that exist at present: The UN Sustainable Development Knowledge Platform, for example, currently lists 3828 partnerships for 
the SDGs. All these partnerships aim to contribute to at least one of the SDGs, and they differ with regard to target groups and main focus areas. Thus, even though partnerships with private-sector actors are nothing new, in addition to the number of partnerships, the forms of cooperation have also multiplied over the past decades. It can be traced back to the Marshall Plan (1948) that governments and the private sector have worked jointly in so-called publicprivate partnerships on large-scale (infrastructure, reconstruction) projects in which sharing risks and resources was an efficient way to tackle big challenges (Sorel and Padoan 2008). Since the launch of the Millennium Development Goals, it has been recognised at different summits and in declarations related to aid effectiveness and financial development agendas that the current challenges of the world cannot be addressed without partnerships that include actors from the private sector.

Before the SDGs, however, in the context of the Millennium Development Goals, the way to engage with the private sector was still incipient. Prior to the 2030 Agenda, the way to achieve multilateral development objectives, which was a common concern related to private-sector engagement, was to find out which forms of cooperation with actors from the private sector could be proposed beyond PPPs. Until then, PPPs, as a term, was predominantly used in bilateral cooperation - it "originates from the sphere of public procurement, and refers to the transfer of responsibility for performing a public task to a private-sector actor" (Federal Ministry for Economic Cooperation and Development [BMZ] 2011, p. 9). In the literature, corporations are mostly related to the provision of goods and services, investments, employment, and technology (UNCTAD 2005), and by extension through PPPs. Moreover, partnerships with actors from the private sector more generally are envisioned to contribute to the achievement of international development agendas by sharing responsibilities, resources, and costs through different channels such as policy dialogues, value chains, knowledge-sharing, technical cooperation, advice, social investment, and finance (Di Bella et al. 2013). In this way, at least six different forms of cooperation with actors from the private sector have been recognised by practitioners in the field of development cooperation and realised by development agencies in the "Global North" and "Global South" (BMZ 2011, p. 6) ${ }^{3}$ :

- sponsoring and co-financing (such as philanthropies),

- multi-stakeholder dialogues and formal networks (such as consultative processes, institutionalised public-private dialogues, multi-stakeholder platforms),

- development partnerships with the private sector (such as strategic alliances, round tables),

- public-private partnerships ${ }^{4}$ (such as service contracts, management contracts, leasings, concessions),

- mobilisation and combination of private and public capital (such as structured funds, securitisation, equity participation), 
- financial and advisory services for private investment in developing countries (such as loans for manufacturing industries, finance for private infrastructure, and finance for small and medium-sized enterprises).

All these types of engagement with the private sector have acquired relevance in recent years (i.a. OECD 2018a). Thus, it comes as no surprise that multi-actor partnerships with private-sector actors are often considered "as important new mechanisms to help resolve a variety of current governance deficits" (Pattberg and Widerberg 2014, p. 9)-irrespective of the form they may take.

\subsection{Means to Support the Success of Private-Sector Engagement in Development CoOperation}

In the 2030 Agenda, multi-actor partnerships with actors from the private sector are seen as crucial instruments for implementing the SDGs (SDG 17). The heterogeneity of partnerships and the respective roles that private-sector actors may take in such partnerships matter even more as a determining factor for the success of partnerships directed towards the SDGs when considering the global scope of the 2030 Agenda and the number of different goals that are summarised under the SDGs. Given the different contextual and internal challenges they have to deal with, the question of how partnerships with actors from the private sector can be more successful is of central relevance in the debate on how to achieve the 2030 Agenda.

Both the more policy-oriented literature and the global governance literature found that the success of partnership initiatives with the private sector very much depends on the institutional oversight provided, among other things, by governmental development agencies and international organisations. We argue that also the different levels at which development agencies and international organisations operate matter greatly. The strategies developed at these different levels are not necessarily aligned. Legal frameworks, development priorities, and the respective mandates differ and shape cooperation with private-sector actors in various ways.

We thus propose to differentiate between the contextual and internal challenges at three levels of engagement for actors from the private sector that contribute to the implementation of the SDGs (either directly or indirectly): global, national, and individual. The global level involves, among other things, companies collaborating in cross-border initiatives with other non-state and state actors. At the national level, the actor's commitment is in a particular country with actions that matter primarily at the national level. Finally, at the individual level, a company decides on its own to undertake a corporate social responsibility strategy or to adopt a sustainable business model that will align its core business to the 2030 Agenda without being linked, allied, or partnered with someone else. The first two formats of cooperation can be 
identified as models of cooperation with actors from the private sector, such as multi-stakeholder dialogues, development partnerships, and PPPs.

When investigating these different levels of engagement and looking at the transnational level of engagement, for example, the case of the GPEDC illustrates that-due to its governance structure and the absence of security for private-sector actors-the potentials and benefits arising from their cooperation in such kinds of partnerships have not been clear. Engaging at the national level ${ }^{5}$ instead seems to provide more advantages for private-sector actors, allowing, among other things, for better knowledge-exchange on regulating frameworks and potentials for cooperation. In this way, the example from Mexico shows how concrete initiatives such as the AS can promote common goals and incentives among private and public actors. This case, however, also illustrates that-judging from the many actors categorised under the term "private sector" - it is still most often multi-national and large local companies that are addressed by development agencies.

When focussing explicitly on internal challenges in partnerships, more policy-oriented research recommends four central actions to support the success of partnerships with private-sector actors in development cooperation-regardless of the distinct objectives, focus areas, modalities of cooperation, or the actors engaged in different forms of multi-stakeholder cooperation (i.a. Brouwer et al. 2015; Prescott and Stibbe 2017; Tennyson 2011; United Nations Global Compact 2013; see also Wehrmann 2018):

1. to clarify the roles that private-sector actors are expected to perform,

2. to encourage transparent and inclusive dialogues,

3. to clarify and specify regulating frameworks early on, and

4. to select the most suitable private-sector actors when considering the overall objectives of the partnership.

To address contextual challenges, researchers from the field of global governance, on the other hand, have often argued in favour of strategies that derive from context-specific, case-by-case assessments and outlined the heterogeneity of partnerships and networks and the difficulties in comparing them (see i.a.Treichel et al. 2016). Following their analysis of the main factors of success for transnational multi-stakeholder partnerships with private-sector actors in the area of sustainable development, Pattberg and Widerberg (2014) further identify three main categories and nine key aspects that contribute to a successful outcome of partnerships (see Table 30.1). 
Table 30.1 Elements contributing to the success of partnerships

\begin{tabular}{ll}
\hline Categories & Key aspects \\
\hline Actors & $\begin{array}{l}\text { 1. Leadership 2. Partners } \\
\text { Process }\end{array}$ \\
$\begin{array}{l}\text { 3. Goal-setting 4. Funding } \\
\text { evaluation, and learning }\end{array}$ \\
Context & 7. Meta-governance 8. Problem structure 9. Political \& social context \\
\hline
\end{tabular}

Source Based on Pattberg and Widerberg (2014, p. 22)

\subsection{Engaging with Private-Sector Actors at the Global LeVEl}

As an SDG partnership, the GPEDC focusses on the implementation of SDG 17. It aims at enhancing knowledge-exchange and capacity-building on a global scale (its members currently include 161 countries and 56 international organisations). To engage with private-sector actors in this regard, the GPEDC implemented a business-leaders caucus (to advise on the GPEDC's guidelines for private-sector engagement) and organised specialised policy dialogues and country-level workshops (e.g. in Bangladesh, Egypt, El Salvador, and Uganda) that were guided by studies conducted under the auspices of the GPEDC. All these activities fall into the category of public-private dialogue and relate to the GPEDC's mandate to achieve the 2030 Agenda by "promoting effective development co-operation geared towards ending all forms of poverty and reducing inequality, advancing sustainable development and ensuring that noone is left behind" (GPEDC 2016, p. 27; Working Party on Aid Effectiveness 2012).

Private-sector actors that engage with the GPEDC are able to participate in events organised by the GPEDC and to learn from and contribute to knowledge-sharing in this regard. Private-sector actors thus receive access to information provided by the members (primarily governments) of the GPEDC, with whom they potentially seek to collaborate as partners in other initiatives (e.g. when entering dialogues with emerging economies). At the same time, they may share their experiences and (knowledge) resources when engaging in dialogues with the members of the GPEDC. More specifically, the GPEDC's monitoring framework, for example, is based on voluntary and country-led reports and provides information on "how effectively governments put in place a conducive environment to maximise the impact of development co-operation and enable contributions from nongovernmental actors" (OECD and United Nations Development Programme 2016, p. 16). Such information can be of help to identify new partners or possibilities for the implementation of initiatives.

The monitoring framework has been criticised, however, for not reflecting the realities in which the GPEDC's partnering actors operate (German Development Institute [DIE] et al. 2017). An exemplary problem that also relates 
to the GPEDC's limited scope of action when trying to incentivise and regulate private-sector engagement in development cooperation (particularly when considering the four central actions to address the internal challenges outlined above) is that, due to the GPEDC's global scope and membership, the GPEDC integrates very different approaches to development cooperation. A comprehensive and sound monitoring framework has to reflect these differences (specifically via the indicators applied for the respective assessments). Similarly, strategies developed under the auspices of the GPEDC to enhance private-sector engagement in development cooperation need to encompass context-specific particularities in its partnering countries. Such strategies thus seem to face the dilemma of either remaining rather general (which contradicts the preferences of private-sector actors to engage in concrete and short-term activities with predictable outcomes) or being too specific to apply to every country.

To deal with this dilemma and to scale-up the impact of partnerships with private-sector actors by addressing the internal and contextual challenges mentioned before, the GPEDC may act as an orchestrator (see Wehrmann 2018). In general, orchestrators and intermediaries cooperate to achieve a shared goal that they are unable to achieve on their own (such as the implementation of the 2030 Agenda). Instead of determining one strategy that is shared by all collaborating partners, the concept of orchestration supports the integration of different approaches and processes (Caplan 2013). It thus recognises that partners have different visions and means for reaching a common goal and enhances the consideration of different contextual challenges (also with regard to the broader field of development cooperation and global governance) as well as the internal challenges arising from the constellation of cooperating actors in the multi-actor partnerships referred to above. As it is up to the orchestrators to set the goal and the related agenda, however, orchestrators are not apolitical or impartial and obtain a more powerful position if compared to the individual and collaborating intermediaries. Although in some regards the GPEDC already operates as an orchestrator (e.g. by providing ideational and material support to like-minded members that also aim at contributing to the implementation of the 2030 Agenda), a main difference is that the GPEDC develops and recommends the use of specific strategies (e.g. to incentivise private-sector engagement) to reach the common goal. An orchestrator, in contrast, facilitates the knowledge-sharing on strategies but leaves it up to the intermediaries to develop different context-specific approaches to advance the shared goal (Fig. 30.1).

When considering the internal challenges and four suggested actions introduced above (to clarify the roles that private-sector actors are expected to perform, to encourage transparent and inclusive dialogues, to clarify and specify regulating frameworks early on, to select the most suitable privatesector actors when considering the overall objectives of the partnership), for a global actor such as the GPEDC, however, several limitations and potentials arise from the application of this concept. 


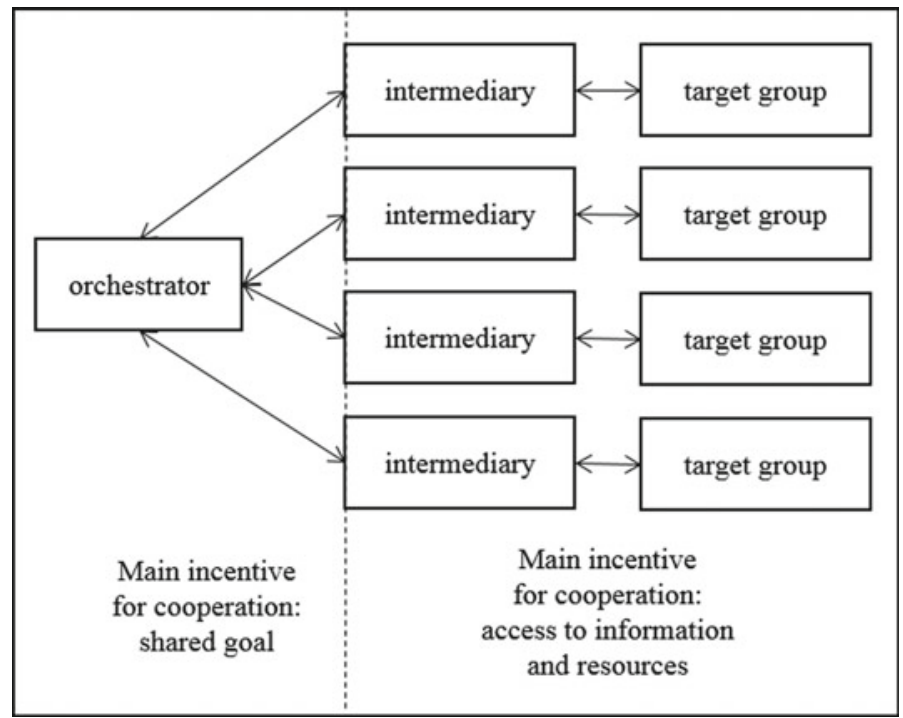

Fig. 30.1 Concept of orchestration (Source Wehrmann [2018])

Firstly, regarding the clarification of the roles that private-sector actors are expected to perform, the GPEDC, as an orchestrating actor, is not in the position to assign whether private-sector actors shall contribute, for example, as resource or knowledge providers to (transnational) multi-actor initiatives or in a specific country setting. However, it can contribute to the suggested clarification in this regard by enhancing transparency on the structures and needs of collaborating partners. To also address the related contextual challenges, the GPEDC, as an orchestrator, can improve the "process" (see Pattberg and Widerberg 2014) of incentivising and regulating private-sector engagement in multi-actor initiatives by informing about (discussing and providing) minimum standards for private-sector engagement (such as the Private-Sector Engagement Principles developed under the auspices of the GPEDC) and by encouraging reflection concerning the goal-setting, funding, management, monitoring, and learning in multi-actor initiatives (as aspects considered in the monitoring provided by the GPEDC).

Secondly, encouraging transparent and inclusive dialogues shall help collaborating partners to adapt and balance priorities, allowing private-sector actors, for example, to better classify the potentials and risks of their engagement. However, as an orchestrating actor, the GPEDC cannot interfere in such dialogue. Still, the country workshops organised under the auspices of the GPEDC provide evidence that the GPEDC is able to enhance such dialogue and to address a central internal challenge in this regard. Via its monitoring framework, it further provides institutional oversight that may improve the effectiveness of such dialogue and thus contributes to the establishment of 
a meta-governance and problem structure, as summarised under the "context" category identified by Pattberg and Widerberg (2014). The country workshops and different summits organised by the GPEDC further encourage knowledge transfers across multi-actor initiatives and contribute to a better understanding and reflection of different political and social contexts.

Thirdly, if regulating frameworks are clarified and specified early on, privatesector actors are more likely to contribute to SDG partnerships. This allows them to develop avenues for balancing different priorities in their endeavours and to justify their cooperation towards their shareholders. Although it is equally important that the GPEDC clarifies and specifies its monitoring framework to avoid any misunderstandings, it is not up to an orchestrating actor to clarify and specify regulating frameworks from partnering countries. Thus, the GPEDC cannot determine the conditions under which its partnering countries collaborate with private-sector actors. This is an internal challenge to be solved at the national levels. However, as mentioned before, the GPEDC can demand and provide transparency on contextual "process" challenges in this regard, for example, concerning the different regulating frameworks that state actors are bound to in their cooperation.

Fourthly, strategies to incentivise private-sector engagement in multi-actor partnerships are more successful if they are adapted towards the specific actor desired to take part in the partnership. It is beyond the scope of the GPEDC to develop such individualised strategies due to the different contexts, the heterogeneity of its partners, and the different functions that private-sector actors may have (e.g. for-profit and state-owned companies). Furthermore, the GPEDC does not obtain the authority to develop such strategies because of the principles to which it is committed. Thus, also this internal challenge cannot be solved at the global level but needs to be addressed at the national level. However, the GPEDC can contribute to the selection process of "actors" by developing recommendations and non-binding guidelines based on experiences from collaborating partners-as it is currently aiming at with its Business Leaders Caucus.

\subsection{Engaging with the Private Sector at The National LeVel}

The case of the AS, on the other hand, illustrates how, at the national level, private-sector engagement can be fostered by multi-stakeholder platforms and how they may contribute through alliances with other actors towards the achievement of the SDGs. The AS was founded in 2013, when AMEXCID, the Mexican cooperation agency created in 2011, developed its own "PrivateSector Collaboration Framework", supported by the Deutsche Gesellschaft für Internationale Zusammenarbeit (GIZ). Its main action principles since then have been: (1) to promote platforms of dialogue that consider inclusive business models and corporate social responsibility, (2) to align PPPs 
with development policies, and (3) to become more cooperation-oriented to improve human capital (Martin et al. 2015).

Although actors from the private sector were not included as relevant actors in the 2011 Mexican Law on International Development Cooperation, the creation of the agency, the launch of the International Development Cooperation Programme 2014-2018 (Programa de Cooperación Internacional para el Desarrollo, PROCID), and later, the narratives promoted by the 2030 Agenda spurred the need to include other non-state actors, such as the private sector, in Mexican development cooperation. The Mexican PROCID 2014-2018, for example, recognised explicitly that the private sector must be included in development cooperation activities of the Mexican government and cites PPPs as one of the main models of engagement (Diario Oficial de la Federación 2014, p. 11).

Accordingly, the AS launched in May 2016 by AMEXCID was designed as a strategic dialogue and cooperation platform with actors from the private sector that may collaborate with civil society, academia, and others. Its purpose has been to promote cooperation projects to achieve the 2030 Agenda in Mexico, Latin America, and the Caribbean. The AS provides contributions (projects oriented towards 5 of the 17 SDGs, as mentioned above) from the local level (a particular country: Mexico) to the regional level (considering the target region that the AS focusses on) by collaborating in particular with the private sector. AMEXCID formed the AS around six principles to guide the effectiveness of cooperation with actors from the private sector to face the challenges of the SDGs in a better way (AMEXCID 2017): (1) shared responsibility in the implementation of the 2030 Agenda, (2) mutual benefits, (3) priority regions, (4) impartiality, (5) transparency and accountability, and (6) replicability. Originally, the AS was supported by 61 firms, 9 entrepreneurial organisations, 12 private foundations, and 4 development agencies. ${ }^{6}$

To make this alliance work and to align efforts towards the SDGs, the participants decided to create five working committees, each of which related to one main SDG: affordable and clean energy (SDG 7), sustainable cities and communities (SDG 11), responsible production and consumption (SDG 12), quality education (SDG 4), and social inclusion (SDGs 8 and 10). AMEXCID saw these issues in particular to be areas where actors from the private sector and AMEXCID could contribute jointly in a more strategic way to cope with two main issues: environmental and social problems in the country.

Even though there is not a quantitative way to measure the degree of achievement so far, following the conceptual framework introduced above, the case of the AS illustrates how it addressed the four proposed actions to overcome internal challenges at the national level (to clarify the roles that private-sector actors are expected to perform; to encourage transparent and inclusive dialogues; to clarify and specify regulating frameworks early on; and to select the most suitable private-sector actors when considering the overall objectives of the partnership) by operating as an orchestrator in parts. 
First, the AS succeeded in defining clear roles for all involved actors. AMEXCID-the orchestrator-provides support and governance around the sharing of benefits, resources, and risks as well as on the identification of needs; the catalysing of resources for projects; the promotion, design, and coordination of projects; and visibility for the AS. The AS can be considered the intermediate channel to engage the private sector. The private sector is mainly expected to contribute with its technical, financial, and innovative capacities, resources, and infrastructure (AMEXCID 2017, p. 8; 2018, pp. 24, 41-42).

Second, the AS is based on reciprocity (in the sense of what actors from the private sector may bring and take from multi-actor development initiatives). Actors from the private sector that cooperate in strategic alliances with development agencies-as in the case of the AS-benefit from cost-sharing (as a result of the public co-financing), increased legitimacy (minimising the usual prejudice against the private sector related to the negative effects of their activity), and access to complementary specialisation (such as organising stakeholder dialogues or facilitating government contacts), helping them to deal with the public administration and governments (see also Altenburg 2005, pp. 2-4). Furthermore, reciprocity is useful to encourage transparency in both sides and inclusive dialogue. In that way, it was proposed, for example, at the fourth meeting of the AS to create a webpage to share best practices and relevant information, as reported by AMEXCID, aligning Mexican cooperation to the principles of "aid effectiveness", transparency, and accountability. This implies that AMEXCID and the private sector, as well as other partners of the AS, are committed to exchanging information, managing cooperation activities jointly, and supporting decisions, thereby facilitating better and more efficient outputs, shared responsibility, and mutual gains (AMEXCID 2017, pp. 5-6).

Third, the AS is based on clear rules and frameworks for cooperation, such as the "Collaboration Framework to Engage with the Private Sector" (AMEXCID 2015, pp. 23-42) and PROCID 2014-2018, which is mandated by Mexican law. According to the theoretical elaborations outlined above, the definition of clear roles, the encouragement of transparency, and inclusive dialogue contribute to the success of partnerships. In addition, given these, there may be a "call effect", that means if the incentives are clear, and if there is reciprocity, the multi-stakeholder dialogue will be transparent, efficient, and accountable; in that regard it will generate trust among others, who will see the AS as a good space to be supported and to collaborate with. The improvement of a partnership will be reflected in its success. This also applies to the AS and, when considering the elements that are considered as contributing to the success of multi-stakeholder partnerships (see Table 30.1), the AS shows that it already includes these elements: The objectives and partners of the AS are clear (actors), as are the leadership, contributions, and the management of the process through the five working committees (process), and its governance is aligned with the framework of the SDGs (context).

Finally, for the fourth point, when considering AMEXCID as performing the role of an "orchestrator", it pushes the AS in various ways: By providing 
the space to meet with other actors, it enhances cooperation in development initiatives and the establishment of strategic links with the public, civil society, foreign governments, international organisations, and particularly with the most suitable private-sector actors, offering all of them national and international resources (AMEXCID 2017, p. 8; 2018, pp. 20-35). Up to now, however, most of the private-sector actors collaborating in the AS are transnational companies with branches in Mexico or large firms that seem to have the initiative, interest, resources, and capacity to engage in an ambitious agenda such as the 2030 Agenda. Here we refer to companies such as ABB, AXA, BBVA, Danone, Deloitte, EY, Gruma, Scotiabank, Nestlé, Pepsico, Pfizer, Schneider, Volkswagen, and Volvo, among others (AMEXCID 2017, p. 6). In that line, the AS operates as an intermediary to achieve the 2030 Agenda at the national level by engaging the private sector (target group). Considering the elements around the way the AS works, it is noticeable that this alliance is not based on a hierarchical structure, since, as was explained above, they work around five committees and are thus based on horizontal dialogue.

Based on the latter, AMEXCID, as an orchestrator, facilitates the implementation of the four actions above. At the same time, the AS can be considered as a case that already successfully applies the central actions to regulate and enhance private-sector engagement outlined above (encouraging transparency and inclusive dialogues, defining regulating frameworks and roles for actors from the private sector, as well as selecting the most suitable private-sector actors). However, when examining the Mexican case in light of the orchestration approach, it is not clear whether there is a need for an actor to operate as orchestrator. In the case of the AS, modes of indirect governance do not seem necessary, as there is such close proximity among actors and good relations that the influence can be almost direct. Moreover, the types of actors (companies, countries, or multilateral platforms) facilitate the relationships among themselves, which allows for regular contact due to the good relationships. However, the approach can be useful to map the way actors could be related to each other and the channels of influence needed to enhance the effectiveness of cooperation platforms, since the AS has shown a specific model of cooperation that leads to the achievement of the SDGs.

In sum, the AS works as a platform of cooperation for different actors. It provides a particular "model" of cooperation to integrate the interests, demands, and concerns of the private sector with local problems that are aligned to the 2030 Agenda. In this way, national development agencies such as AMEXCID aim at providing a more inclusive and strategic cooperation beyond borders, particularly in the five SDGs targeted by the AS. Selfassessments of the processes that have been realised through the experience, such as the 2018 "Prototype of the AS" (AMEXCID 2018), provide initial evaluations to improve the process and enhance the quality of private-sector engagement. 


\subsection{Conclusions and Policy Recommendations}

By focussing on different levels of engagement, the cases of the AS and of the GPEDC illustrated how cooperation with private-sector actors in development cooperation can be improved. At the national level, the case of the AS showed that, although guidance provided by a partner with more experience with private-sector engagement stimulated the national development agency to form an alliance with private-sector actors, once it was established, no further indirect governance seemed necessary to keep these actors engaged in the initiative. Instead, horizontal dialogue facilitated the identification of topics that all the engaged actors were interested in working on. In the AS, AMEXCID can be seen as an "orchestrator-light". Even though it implemented the respective committees and has been evaluating the AS, thus taking over institutional responsibilities, AMEXCID does not use intermediaries in its collaboration with private-sector actors but addresses them directly. In contrast, at the global level, the GPEDC would benefit from scaling-up its orchestrating capacities, particularly by providing more institutional regulation to overcome very general approaches that neglect context-specific particularities, thus remaining very vague and not allowing private-sector actors to identify the benefits arising from such collaborations at first glance. However, the GPEDC already operates as an orchestrator when considering its mode of cooperation with national development agencies, which act as intermediaries when providing, for example, all necessary information for the monitoring provided by the GPEDC.

The following lessons emerge from the case of the AS and can be transferred to international dialogues and platforms such as the GEPDC:

1. The case of the AS exemplifies that, at the national level, private-sector actors are already engaged in development initiatives to achieve the 2030 Agenda. In the case of the AS, however, these are mostly multi-national or large local companies and not smaller firms.

2. As a multi-actor partnership, the AS already applies the four central actions often suggested to enhance private-sector engagement in development cooperation. These central actions can be considered as having contributed to the success of the AS in its collaboration with privatesector actors.

3. The AS seems to have also benefitted from the guidance provided by a leading institution (AMEXCID) and its regulatory framework that legitimated the leadership and cooperation with other official, private, social, and international actors. ${ }^{7}$

4. At least in a middle-income country such as Mexico (which plays a dual role in terms of international cooperation as a provider and recipient), it is important that the leading institution (in this case AMEXCID) had the support of development partners with more experience (in this case GIZ), which contributed to the development of responses to the multiple 
challenges that come along with the 2030 Agenda requiring collaboration at different levels, not only locally. This is key in a country where there may be some other local priorities and a lack of human resources to develop collaboration frameworks in a short period of time.

5. The case of the AS shows that it is important to work closely with the private sector to define the relevant topics of interest and to align them with the SDGs in a horizontal dialogue so that they make sense to the involved actors and mirror local needs.

6. To advance the implementation of the 2030 Agenda through the engagement of private-sector actors in development initiatives, the AS process provides evidence that clear rules and incentives matter greatly as well as the commitment to acknowledge local needs.

We do not claim that the cases of the AS and of the GPEDC are representative for all multi-actor partnerships. Further evidence and research are needed to investigate whether the identified factors of success are transferable to partnerships in other countries. However, despite the differences also among the two cases examined, from our analysis of internal and contextual challenges at the different levels of engagement in development cooperation, we derived two results that seem central for the success of partnerships with private-sector actors:

1. The cases of the AS and of the GPEDC have shown that, at the national level, it seems to be easier to enhance and maintain the engagement of private-sector actors in development initiatives because the terms of cooperation are more specific. This is particularly relevant in the context of the 2030 Agenda to specify expected outcomes according to local needs and to generate ownership in the process. Thus, national development agencies are important focal points whose efforts need to be strengthened when aiming at incentivising private-sector engagement in development cooperation.

2. To scale-up the impact of multi-stakeholder initiatives with private-sector actors, both at the global and national levels, monitoring frameworks are needed. Although they should be aligned with the 2030 Agenda in order to evaluate the expected outcomes of such initiatives, it is necessary to differentiate between the different formats of multi-actor partnerships and the settings in which they operate. The GPEDC and the AS, for example, try to enhance private-sector engagement for different purposes, as both partnerships are driven by different objectives. Ideally, the evaluation results deriving from such frameworks are used as a basis for further dialogue across the different levels of engagement-for example among AMEXCID and other development agencies in emerging economies or the GPEDC-to enhance knowledge transfer and the identification of unused potentials and challenges for international and South-South initiatives. 
Although these results imply responsibilities particularly for governing actors in multi-actor partnerships, there is no doubt that the success of partnerships with private-sector actors depends on the commitment of all involved actors, including private-sector actors. In this way, it is crucial that privatesector actors feel a responsibility to contribute to the implementation of the 2030 Agenda, but at the same time that they acknowledge the principle of country ownership and do not undermine related processes, for example, by not providing access to information that is relevant for monitoring and evaluation mechanisms. However, this is also a matter of communication for which, following the principle of country ownership, governments should be held responsible.

\section{Notes}

1. Despite its heterogeneity, scholars and practitioners often relate to "the private sector" or "the business sector" in general terms without specifying the kind of for-profit actor they are referring to. The possibilities and roles of privatesector actors in development cooperation initiatives, however, differ and also depend on their size, structure, and ownership — as do the knowledge, innovations, and investments they may be able to provide to implement the SDGs. In general, particularly small and medium-sized enterprises, multinational corporations, state-owned enterprises, as well as business-related private foundations operating on a non-profit basis are regarded as important partners in sustainable development partnerships. In this chapter, we relate to all these actors when using the term "private sector".

2. When considering the different formats of cooperation that are summarised under the umbrella of South-South Cooperation, it becomes clear that neither practitioners nor researchers share a similar understanding of what SouthSouth cooperation actually (can) encompass(es) (Fues 2016; Renzio and Seifert 2014). It is, however, a widespread perception that collaboration with partners from "the South" is less paternalistic than with traditional partners. This supports the understanding that partnerships are to a greater extent motivated by the notion of solidarity (Argente-Linares et al. 2013; Finance Center for South-South Cooperation 2017; Renzio and Seifert 2014, 1861f.; Stijns 2011; United Nations Executive Office of the Secretary-General and United Nations Framework Convention on Climate Change 2017).

3 . For a brief summary of private-sector engagement in the context of the 2030 Agenda and public-private forms of collaboration, see Pérez-Pineda (2017, pp. 97-99), and for a guide to integrate the SDGs through the private sector, see Global Reporting Initiative et al. (2015).

4. Within PPPs, variants can be found that are shaped by a different degree of strategic engagement and number of actors. Hence, authors such as GómezGalán and Sainz (2014) and Casado (2007) consider three types: (1) In the context of public-private collaborations, for example, one common format of engagement between the public and private sectors relates to public procurement or subcontracting; (2) public-private partnerships are based on a service or management contract, or joint investments, according to which risks are shared. These two models usually build on a client-provider relationship among 
the public and private sectors; (3) public-private partnerships for development (PPPDs) are understood as initiatives in which, apart from actors from the public and private sectors, civil society and academia are involved with joint action, sharing risks, benefits, and targets oriented to development (Mataix et al. 2008, pp. 10-12). PPPDs can be considered as being more consistent with the multi-actor dialogue approaches.

5. The individual level of engagement (potentials and challenges of private-sector actors to collaborate in partnerships) is also of great significance when discussing different levels of engagement, but it is not systematically considered in the chapter, as these internal matters do not directly relate to the question of how multi-stakeholder initiatives can be improved. It is, however, noticeable that companies more often use the 2030 Agenda as a reference point-especially transnational companies that engage in international markets and face the respective competition.

6. Its main objectives are: to share and spread successful cases of using the SDGs into business models; to identify strategic priorities and activities that are pro-SDG between the public and private sectors; to design and implement sustainable development projects in Mexico, Central America, and the Caribbean; to develop capacities for the private sector to implement the SDGs into their business models; to create strategic alliances for development with civil society as well as local and state governments; to define and execute financial plans through development banks, private funds, and other development funds; to build tools for monitoring the advancement of the 2030 Agenda (see: https://www.gob.mx/amexcid/es/acciones-y-programas/alianzapor-la-sostenibilidad).

7. Some of these lessons coincide with findings of Abbott and Bernstein (2015) that are related to conditions for the success of an orchestration strategy, particularly legitimacy and focal institutional position.

\section{REFERENCES}

Abbott, K., \& Bernstein, S. (2015). The high-level political forum on sustainable development: Orchestration by default and design. Global Policy, 6(3), 222-233.

Abbott, K. W., Genschel, P., Snidal, D., \& Zangl, B. (2016). Two logics of indirect governance: Delegation and orchestration. British Journal of Political Science, 46(4), 719-729.

Abshagen, M.-L., Cavazzini, A., Graen, L., \& Obenland, W. (2018). Analysis: Hijacking the SDGs? The private sector and the sustainable development goals (Analysis 78). https://www.globalpolicy.org/images/pdfs/GPFEurope/Hijacking_ the_SDGs.pdf.

Adams, B., \& Martens, J. (2015). Fit for whose purpose? Private funding and corporate influence in the United Nations. https://sustainabledevelopment.un.org/content/ documents/2101Fit_for_whose_purpose_online.pdf.

Altenburg, T. (2005). The private sector and development agencies: How to form successful alliances. Critical issues and lessons learned from leading donor programs (DIE Discussion Paper). Bonn: German Development Institute / Deutsches Institut für Entwicklungspolitik (DIE). 
AMEXCID (Agencia Mexicana de Cooperación Internacional para el Desarrollo). (2015). "Marco de Colaboración con el Sector Privado para la Cooperación Internacional para el Desarrollo". In J. Martin, D. Angelino, \& L. López, Construcción de una estrategia de colaboración de AMEXCID con el sector privado (pp. 23-42). Proyecto de Cooperación para el Fortalecimiento Institucional de la AMEXCID (Documento 4). https://www.gob.mx/cms/uploads/attachment/file/124687/ 160530_Documentacion_Sector_Privado_AMEXCID-_GIZ_Copy_VF.pdf.

AMEXCID. (2017). Alianza por la sostenibilidad: Visión para la vinculacion con el sector privado. https://www.gob.mx/cms/uploads/attachment/file/273197/ Visi_n_de_la_AxS.pdf.

AMEXCID. (2018). La alianza por la sostenibilidad: Un prototipo de la AMEXCID para la vinculación con el sector privado. Ciudad de México: SRE, Author, AxS, GIZ.

Argente-Linares, E., López-Pérez, M. V., \& Rodríguez-Ariza, L. (2013). Organizational structure and success of international joint ventures in emerging economies: The case of Spanish-Moroccan SMEs. Review of Managerial Science, 7(4), 499-512.

Beisheim, M., \& Liese, A. (Eds.). (2014). Transnational partnerships: Effectively providing for sustainable development? London: Palgrave Macmillan.

BMZ (Federal Ministry for Economic Cooperation and Development). (2011). Forms of development cooperation involving the private sector. https://www.bmz.de/en/ publications/archiv/type_of_publication/strategies/Strategiepapier306_05_2011. pdf.

Brouwer, H., Woodhill, J., Hemmati, M., Verhoosel, K., \& van Vugt, S. (2015). The MSP guide: How to design and facilitate multi-stakeholder partnerships. Wageningen, NL: Centre for Development Innovation.

Byiers, B., Guadagno, F., \& Karaki, K. (2015). From looking good to doing good: Mapping CSO business partnerships (Discussion Paper No. 182). Maastricht: European Centre for Development Policy Management.

Caplan, K. (2013). Taking the mythology out of partnerships-A view from the ground up. http://www.bpdws.org/web/d/DOC_359.pdf?statsHandlerDone=1.

Casado, F. (2007). Las alianzas público privadas para el desarrollo (Documento de trabajo no. 9). Madrid: Fundación Carolina- CeALCI.

Chan, S. (2014). Partnerships for sustainable development emergence: Adaptation and impacts in global and domestic governance contexts. Dissertation, Amsterdam: Universiteit Amsterdam.

Chan, S., \& Pauw, P. (2014). A global framework for climate action (GFCA): Orchestrating non-state and subnational initiatives for more effective global climate governance (DIE Discussion Paper 34). Bonn: German Development Institute / Deutsches Institut für Entwicklungspolitik (DIE).

Davis, P. (2011). The role of the private sector in the context of aid effectiveness. Consultative findings document. http://www.oecd.org/dac/effectiveness /470 88121.pdf.

Development Cooperation Forum. (2017). DCF Argentina high-level symposium. https://www.un.org/ecosoc/sites/www.un.org.ecosoc/files/files/en/dcf/dcf-arg entina-summary.pdf.

Diario Oficial de la Federación. (2014, April 30). Decreto por el que se aprueba el Programa de Cooperación Internacional para el Desarrollo 2014-2018. http://sre. gob.mx/images/stories/marconormativodoc/nor2014/dof300414.pdf. 
Di Bella, J., Grant, A., Kindornay, S., \& Tissot, S. (2013). How to engage the private sector for development. Ottawa: The North-South Institute.

DIE (German Development Institute), Federal Ministry for Economic Cooperation and Development, \& Global Partnership for Effective Development Co-operation. (2017). Towards a shared understanding of effective development co-operation: Learning from different sectors and approaches. Informal exchange. https://www.die-gdi.de/uploads/tx_veranstaltung/20171124_ Informal_Exchange_with_Researchers_from_Emerging_Economies_summary.pdf.

Finance Center for South-South Cooperation. (2017). South-South cooperation report. Changing roles of South-South cooperation in global development system: Towards 2030. Hong Kong: Author.

Fues, T. (2016, April 11). Süd-Süd-Kooperation: Globaler Akteur mit unklarer Identität (DIE Die aktuelle Kolumne). Bonn: German Development Institute / Deutsches Institut für Entwicklungspolitik (DIE).

Global Reporting Initiative, United Nations Global Compact, \& World Business Council for Sustainable Development. (2015). SDG compass. https://sdgcompass. $\operatorname{org} /$.

Gómez-Galán, M., \& Sainz, H. (2014). Alianzas público-privadas para resultados de desarrollo: Una guía para la gestión. Madrid: Fundación CIDEAL.

GPEDC (Global Partnership for Effective Development Co-operation). (2016). Nairobi outcome document. http://effectivecooperation.org/wp-content/uploads/ 2016/12/OutcomeDocumentEnglish.pdf.

GPEDC. (2018). Agenda 2030: Promoting effective private sector engagement through development co-operation. http://effectivecooperation.org/wp-content/upl oads /2018/01/Private-Sector-Engagement-Concept-Note.pdf.

GPEDC. (2019). Private sector engagement through development co-operation. https://effectivecooperation.org/our-work/2017-2018-programme-of-work/pri vate-sector-engagement-through-development-co-operation/.

International Labour Organization. (2017). Tripartite declaration of principles concerning multinational enterprises and social policy. Fifth Edition. http://www. ilo.org/wcmsp5/groups/public/—ed_emp/—emp_ent/—multi/documents/pub lication/wcms_094386.pdf.

Kindornay, S., \& Reilly-King, F. (2013). Investing in the business of development: Bilateral donor approaches to engaging with the private sector. http://www.nsi-ins.ca/wpcontent/uploads/2013/01/2012-The-Business-of-Development.pdf.

Martin, J., Angelino, D., \& López, L. (2015). Construcción de una estrategia de colaboración de AMEXCID con el sector privado. Proyecto de Cooperación para el Fortalecimiento Institucional de la AMEXCID (Documento 4). https://www.gob.mx/cms/uploads/attachment/file/124687/160530_ Documentacion_Sector_Privado_AMEXCID-_GIZ_Copy_VF.pdf.

Mataix, C., Sánchez, E., Huerta, M. A., \& Lumbreras, J. (2008). Cooperación para el desarrollo y alianzas público-privadas: Experiencias internacionales y recomendaciones para el caso español (Documento de trabajo no. 20). Madrid: Fundación CarolinaCeALCI.

Mawdsley, E. (2015). DFID, the private sector and the re-centring of an economic growth agenda in international development. Global Society, 29(3), 339-358.

Mawdsley, E. (2018). "From billions to trillions": Financing the SDGs in a world "beyond aid". Dialogues in Human Geography, 8(2), 191-195. 
Nelson, J., \& Prescott, D. (2008). Business and the millennium development goals: $A$ framework for action. London and New York, NY: United Nations Development Programme and the International Business Leaders Forum.

OECD (Organisation for Economic Co-operation and Development). (2011). OECD guidelines for multinational enterprises. Paris: OECD Publishing.

OECD. (2018a). Global outlook on financing for sustainable development 2019: Time to face the challenge. Paris: OECD Publishing.

OECD. (2018b). Development co-operation report 2018: Joining forces to leave no one behind. Paris: OECD Publishing.

OECD \& United Nations Development Programme. (2016). Making development co-operation more effective: 2016 progress report. Paris: OECD Publishing.

Pattberg, P., \& Widerberg, O. (2014). Transnational multi-stakeholder partnerships for sustainable development: Building blocks for success. http://dx.doi.org/10.2139/ ssrn.2480302.

Pérez-Pineda, J. A. (2017). El sector privado en el cumplimiento de los ODS: La experiencia Mexicana. Revista Española de Desarrollo y Cooperación, 40, 93-103.

Pingeot, L. (2014). La influencia empresarial en el proceso post-2015: Cuadernos 2015 y más. Obeservatorio de Multinacionales en América Latina. http://omal.info/IMG/ pdf/cuaderno_4_digital.pdf.

Prescott, D., \& Stibbe, D. (2017). Better together: Unleashing the power of the private sector to tackle non-communicable diseases. A guidebook for collaboration between nonprofit organisations and businesses. Oxford, Geneva, and London: The Partnering Initiative, Union for International Cancer Control, and Bupa.

Renzio, P. d., \& Seifert, J. (2014). South-South cooperation and the future of development assistance: Mapping actors and opinions. Third World Quarterly, 35(10), $1860-1875$.

Romero, M. J. (2015). What lies beneath? A critical assessment of PPPs and their impact on sustainable development. http://eurodad.org/files/pdf/559e6c832c087. pdf.

Said, A. A., Lerche, C. O., Jr., \& Lerche, C. O., III. (1995). Concepts of international politics in global perspective. Englewood Cliffs, NJ: Prentice Hall.

Sorel, E., \& Padoan, P. C. (2008). The marshall plan: Lessons learned for the 21st century. Paris: OECD Publishing.

Stijns, J.-P. (2011). Africa's emerging partnerships. OECD Observer, 285(Q2), 17-18.

Tennyson, R. (2011). The partnering toolbook: An essential guide to cross-sector partnering. https://thepartneringinitiative.org/wp-content/uploads/2014/08/Partne ring-Toolbook-en-20113.pdf.

The North-South Institute. (2013). Mapping private sector engagements in development cooperation. http://www.nsi-ins.ca/wp-content/uploads/2013/09/MappingPS-Engagment-in-Development-Cooperation-Final.pdf.

Tienhaara, K., Orsini, A., \& Falkner, R. (2012). Global corporations. In F. Biermann \& P. Pattberg (Eds.), Global environmental governance reconsidered (pp. 45-68). Cambridge, MA: The MIT Press.

Treichel, K., Höh, A., Biermann, S., \& Conze, P. (2016). Multi-AkteursPartnerschaften im Rahmen der Agenda 2030: Eine praxisorientierte Analyse von Potentialen, Herausforderungen und Erfolgsfaktoren. https://www.partnerschaf ten2030.de/wp-content/uploads/2017/09/Viadrina_Governance_MAP-Studie_ WEB.pdf. 
UNCTAD (United Nations Conference on Trade and Development). (2005). UNCTAD: Positive corporate contributions to the economic and social development of host developing countries, TD/B/COM.2/EM.17/2. https://unctad.org/en/Docs/ c2em17d2_en.pdf.

UNCTAD. (2015). UNCTAD: Investing in sustainable development goals: Action plan for private investments in SDGs. https://unctad.org/en/PublicationsLibrary/osg 2015d3_en.pdf.

United Nations. (2009). Guidelines on cooperation between the United Nations and the business sector. http://www.un.org/ar/business/pdf/Guidelines_on_UN_Busi ness_Cooperation.pdf.

United Nations Development Programme. (2017). Impact investment to close the SDG funding gap. https://www.undp.org/content/undp/en/home/blog/2017/ 7/13/What-kind-of-blender-do-we-need-to-finance-the-SDGs-.html.

United Nations Executive Office of the Secretary-General \& United Nations Framework Convention on Climate Change. (2017). Catalysing the implementation of nationally determined contributions in the context of the 2030 agenda through South-South cooperation. https://www.un.org/sustainabledevelopment/wpcontent/uploads/2017/05/Download-Report.pdf.

United Nations General Assembly. (2018). Role of South-South cooperation and the implementation of the 2030 agenda for sustainable development: Challenges and opportunities. http://www.un.org/ga/search/view_doc.asp?symbol=A/ $73 / 383 \&$ Lang=E.

United Nations Global Compact. (2013). UN-business partnerships: A handbook. https://www.unglobalcompact.org/docs/issues_doc/un_business_partnerships/ UNBusinessPartnershipHandbook.pdf.

Wehrmann, D. (2018). Incentivising and regulating multi-actor partnerships and private-sector engagement in development cooperation (DIE Discussion Paper 21). Bonn: German Development Institute / Deutsches Institut für Entwicklungspolitik (DIE).

Working Party on Aid Effectiveness. (2012). Proposed mandate for the global partnership for effective development co-operation. Paris: United Nations Educational, Scientific and Cultural Organization.

Open Access This chapter is licensed under the terms of the Creative Commons Attribution 4.0 International License (http://creativecommons.org/licenses/by/4.0/), which permits use, sharing, adaptation, distribution and reproduction in any medium or format, as long as you give appropriate credit to the original author(s) and the source, provide a link to the Creative Commons license and indicate if changes were made.

The images or other third party material in this chapter are included in the chapter's Creative Commons license, unless indicated otherwise in a credit line to the material. If material is not included in the chapter's Creative Commons license and your intended use is not permitted by statutory regulation or exceeds the permitted use, you will need to obtain permission directly from the copyright holder.

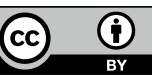

